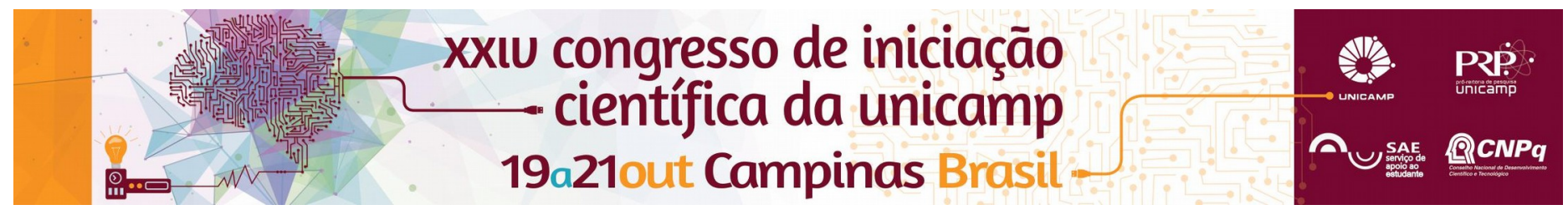

\title{
O uso sociológico do pensamento darwiniano no Brasil: laboratório racial.
}

\section{*Diogo Valmor Pereira}

\begin{abstract}
Resumo
O projeto tem como ponto de partida analisar a recepção que a teoria darwiniana teve no Brasil em fins do século XIX e começo do XX e compreender o seu uso sociológico, por parte da chamada Escola Nina Rodrigues, analisar como alguns intelectuais dessa Escola usaram, adaptaram e readequaram os postulados de Darwin para debater questões relativas a cidadania, cultura e identidades no Brasil, que vinha passando por profundas mudanças sociais, políticas e culturais.
\end{abstract}

Palavras-chave:

Escola Nina Rodrigues; Teorias Raciais; Cidadania

\section{Introdução}

Teorias raciais sempre existiram nas ciências sociais, mas a pergunta que fica é porque depois das publicações de Darwin, essas teorias ganharam novas reformulações e porque especificamente no Brasil do final do século XIX e começo do século $X X$ o seu uso sociológico na produção e interpretação das questões sociais ficaram ainda mais presentes? Sendo criada toda uma escola de pensamento e tradições evolucionista? Entender o papel dos intelectuais do Brasil do século XIX é de extrema importância para essa pesquisa, pois só assim, conseguiremos observar na recepção das teorias de Darwin, aspectos que foram utilizadas por estes intelectuais para dissertarem sobre assuntos que se relacionavam com um ideal de nação para o Estado brasileiro através de projetos, visões e planos para a nação brasileira. A chamada Escola Nina Rodrigues, cumpre um importante papel nessa busca do Estado por "identidades" para o rumo da nação, a escola parece ter absorvido o que Silvio Romero chamou de "bando de ideias novas", pois, a produção desta está diretamente ligada ao debate sobre raça, racismo, cidadania e cultura no Brasil em meados do final do século XIX.

\section{Resultados e Discussão}

Partindo de duas obras iniciais que compõem a bibliografia selecionada, conseguimos mapear primeiro a formação e papel das Instituições acadêmicas a partir de 1870 e quais os debates em voga nesse período, a exemplo: miscigenação\&progresso nacional, para isso o trabalho de Lilia Schwarcz, em seu livro, O Espetáculos das Raças, de 1993, tem sido imprescindível. A autora trás para o debate a força política das instituições cientificas; como a produção acadêmica dos intelectuais brasileiros entravam em consonância com as questões sociais que o Estado não perdia de vista, ainda mais em um período em que o Brasil era conhecido internacionalmente como um laboratório racial.

Um segundo ponto de partida foi entender o papel da Escola Nina Rodrigues e as redes políticas, que se formaram dentro da Instituições acadêmicas, para isso selecionamos dois intelectuais dessa escola, Nina Rodrigues, por ser mentor de diversos desses cientistas e por estar presente em seus trabalhos o tema da miscigenação; o outro autor é Afrânio Peixoto, por estar inserido em um contexto em que a República brasileira se encontra mais "amadurecida" e a questão racial estava sendo amplamente debatida pelo grupos sociais.

Para essa segunda parte selecionamos o livro, As Ilusões da liberdade: a Escola Nina Rodrigues e a Antropologia no Brasil, lançado em 1998, de Mariza Corrêa. O trabalho da autora contribuiu para a pesquisa, pois a sua pesquisa inova na observação, não somente do papel da Escola Nina Rodrigues, mas na falta de fronteiras definidas na ciência do séc. XIX e que podem ser um dos fatores para o "boom" evolucionista presente na história da ciência brasileira.

Outros trabalhos importantes tem nos norteado a respeito da recepção que a teoria de Darwin teve no Brasil, trabalhos que implicam não necessariamente em seu uso sociológico, mas que ampliam o campo de visão sobre o Brasil, suas instituições e seus intelectuais do séc. XIX.

\section{Conclusão}

O que se tem notada em nossa pesquisa, é que apesar do cunho biologizante, a produção acadêmica do século $\mathrm{XIX}$, se mostravam preocupada com o rumo nação, porém a falta de barrerias bem definidas entre os saberes científicos proporcionou que teorias raciais e de caráter excludente fossem predominantes no pensamento brasileiro do período, o que pode ser transportado para outros campos, como sociedade civil, política, literatura e até mesmo no senso comum.

\section{Agradecimentos}

Agradeço ao CNPQ, pelo financiamento. Mário Augusto, pela excelente orientação. Patricia, pela paciência. Minha irmã, Juliana, por estar sempre presente.

${ }^{1}$ CORRÊA, Mariza. As Ilusões da Liberdade: a Escola Nina Rodrigues e a antropologia no Brasil. $2^{\circ}$ Ed. Bragança Paulista - SP: Editora da Universidade São Francisco, 2001. Coleção Estudos CDAPH. Série Memória.

${ }^{2}$ SCHWARCZ, Lilia Moritz. O espetáculo das raças: cientistas, instituições e questão racial no Brasil 1870- 1930. São Paulo- SP: Companhia das letras, 1993. 